\title{
HARMADLAGOS KŐOLAJKITERMELÉSRE ALKALMAZOTT TENZIDEK ÖSSZEHASONLÍTÓ VIZSGÁLATA
}

\section{COMPARATIVE INVESTIGATION OF SURFACTANTS FOR ENHANCED OIL RECOVERY}

\author{
Nagy Roland ${ }^{1}$, Kothencz Réka ${ }^{2}$, Bartha László3 ${ }^{3}$ Vágó Árpád ${ }^{4}$ \\ ${ }^{I}$ Pannon Egyetem, Mérnöki kar, MOL Ásványolaj-és Széntechnológia Intézeti \\ Tanszék, Magyarország, 8200 Veszprém, Egyetem utca 10.; Telefon: +3688/ 624- \\ 412,nroland@almos.uni-pannon.hu \\ ${ }^{2}$ Pannon Egyetem, Mérnöki kar, Vegyipari Müveleti Intézeti Tanszék, Magyarország, \\ 8200 Veszprém, Egyetem utca 10.; Telefon:+3688/624-305, kothenczr@almos.uni- \\ pannon.hu \\ ${ }^{3}$ Pannon Egyetem, Mérnöki kar, Vegyipari Müveleti Intézeti Tanszék, Magyarország, \\ 8200 Veszprém, Egyetem utca 10.; Telefon: +3688/624-305, bartha@almos.uni- \\ pannon.hu
}

${ }^{4}$ MOL NyRt, Csoportszintü Kutatás és Üzletfejlesztés, 1117 Budapest, Októberhuszonharmadika utca 18., avago@mol.hu

\begin{abstract}
In the past few decades, considerable researches have been done around the world for increase the oil production; one of the most perspective processes is the chemical enhanced oil recovery. The mixture of polymers and surfactants were used, therefore various surfactant test methods must be developed in order to the surfactant or their mixture would be effective. Surfactant mixtures were prepared and the test methods for their characterization were elaborated for chemical EOR (Enhanced Oil Recovery). The examination of oil flushing effect and emulsifying effect were described. It was found that the surfactants used in EOR should be developed depending on the circumstances of the given area.
\end{abstract}

Keywords: chemical EOR, method development, reservoir conditions.

\section{Összefoglalás}

Az elmúlt néhány évtizedben világszerte jelentős kutatásokat végeztek kőolajtermelés fokozásával kapcsolatban, az egyik leginkább perspektívikus eljárás a kémiai harmadlagos kőolajkitermelés. Ennek során polimerek és tenzidek keverékét használják fel, ezért a tenzidek fejlesztése során különbözö vizsgálati módszereket kell kidolgozni annak érdekében, hogy a tenzid illetve tenzidkeverék hatékony legyen. Kémiai EOR (Enhanced Oil Recovery) célokra állítottunk elő tenzideket illetve tenzidkompozíciókat, melyek jellemzésére laboratóriumi vizsgálati módszereket dolgoztunk ki. Ezek közül az olajkimosóhatás és az emulgeáló hatás vizsgálatát ismertettük. Megállapítottuk, hogy a felhasználandó tenzideket az adott kőolajmező tárolórétegének körülményeihez kell illeszteni.

Kulcsszavak: kémiai EOR, módszerfejlesztés, rétegkörülmények. 


\section{Bevezetés}

Az elmúlt néhány évtizedben világszerte jelentős kutatásokat végeztek kőolajtermelés fokozásával kapcsolatban, mivel a kitermelési hatásfok a földtani készletre vonatkoztatva meglepöen kicsi, átlagosan $\quad 30-35 \%$. A leghatékonyabb harmadlagos kőolajkitermelési típus, a polimer-tenzides elárasztás során különböző folyadékokat (tenzid oldatot, polimer oldatot, majd vizet) juttatnak a rétegbe a besajtoló kutakon keresztül. Ennek hatására a vízdugó nyomja maga elött a polimer- és a tenzidoldatot. A tenzid a rétegvízzel és a kőolajjal emulziót képezve csökkenti az olaj határfelületi feszültségét (IFT), így lehetőség nyílik arra, hogy a lefüzödött olajrészecskéket a pórusokon átnyomva a termelőkúton távozzanak [1]. Az EOR során alkalmazott felületaktív anyagokkal szemben támasztott fontos követelmény, hogy a tározóban lévö folyadékfázisok között a lehetö legalacsonyabb határfelületi feszültséget biztosítani tudják, melynek következtében a csapdázódott olaj mobilizálódni tud a póruscsatornákon keresztül. A tenzidek fejlesztése során különböző vizsgálati módszereket kell alkalmazni annak érdekében, hogy a tenzid illetve tenzidkeverék hatékony legyen $[2,3]$.

Munkánk során célunk volt a kőolajtároló réteg körülményeit megközelítő laboratóriumi hatásvizsgálati módszerek kidolgozása és a modell vizsgálatokkal végzett mérésekkel történő összehasonlítása.

\section{Felhasznált anyagok}

A vizsgálatok során különböző algyői tározókból származó rétegvizet, kőolajat, valamint a Pannon Egyetem Müszaki Kutató Intézetében (MÜKKI) és a MOL Ásványolaj- és Széntechnológiai Intézeti Tanszékén kifejlesztett anionos és nemionos tenzideket használtunk fel. Ezen anyagokhoz, a kitermelési hatásfok növelését szolgáló folyásmódosító polimert is adtunk.

\section{Alkalmazott módszerek}

Az EOR célú tenzidek jellemzésére nincs szabványos laboratóriumi minősítő módszer, illetve módszercsomag, ezért ezek kidolgozására volt szükség.

\subsection{Olajkimosó hatás vékonyréteg kromatográfiás meghatározása}

Szakirodalmi közlemények olyan komplex felületaktív hatást jellemző módszert nem közöltek, mellyel a kőolaj pórusos kőzetfelületről történő lemosásának mértékét jellemezni lehetne. Ezért fejlesztettük ki a szerves kémiai analízisben régóta alkalmazott vékonyréteg kromatográfiás módszer alapjain nyugvó olajkimosó hatás vizsgálati módszerét. Tapasztalataink alapján ezáltal az egyes nemionos tenzidek és az elóállított tenzidkompozíciók ilyen irányú hatása is jellemezhető.

\subsection{Emulgeáló hatás vizsgálata}

A kémiai EOR alapelvéből következik, hogy a kőzet felületéről történő kőolaj leoldása, illetve leszorítása a meghatározó részfolyamatokhoz tartoznak. Emellett a tenzid jó emulgeáló képessége is szükséges jellemzö, amely kedvező viszkozitású $\mathrm{O} / \mathrm{V}$ típusú emulziót eredményezhet. $\mathrm{Az}$ emulgeálókapacitás az egyes ülepített fázisok térfogatszázalékos mennyiségével jellemezhető.

\section{Mérési eredmények}

\subsection{Olajkimosó hatás vizsgálata}

A kidolgozott módszer alapján megvizsgáltuk, hogy a tenzidkompozíciók olajkimosó hatása hogyan változik az összetétellel. Az eredményeket az 1. táblázat és az 1. ábra szemlélteti. 
1. táblázat. Olajkimosó hatás vizsgálati eredményei modell- és valós körülmények között

\begin{tabular}{|c|c|c|}
\hline $\begin{array}{c}\text { Kompozíció } \\
\text { jele }\end{array}$ & $\begin{array}{c}\text { Olajkimosó } \\
\text { hatás, modell } \\
\text { víz }(\mathrm{mm})\end{array}$ & $\begin{array}{c}\text { Olajkimosó } \\
\text { hatás, valós } \\
\text { rétegvíz } \\
(\mathrm{mm})\end{array}$ \\
\hline KO-1 & 12 & 24 \\
\hline KO-2 & 20 & 22 \\
\hline KO-3 & 18 & 21 \\
\hline KO-4 & 19 & 26 \\
\hline KO-5 & 14 & 24 \\
\hline
\end{tabular}

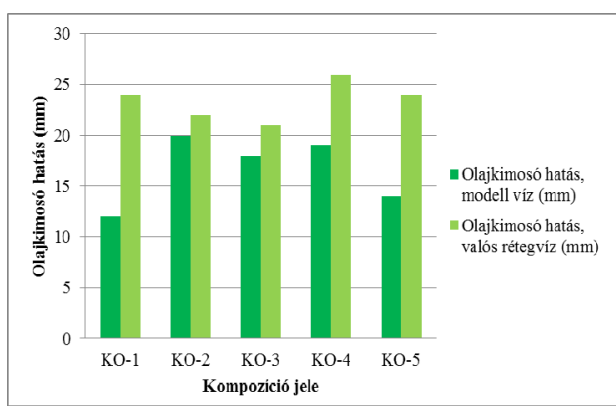

1. ábra. Olajkimosó hatás vizsgálati eredményei modell-és valós körülmények között

Megállapítottuk, hogy a kőolajtároló rétegkörülményeit megközelítő kondíciók mellett végzett vizsgálatok minden esetben eltértek a modellvizsgálatok eredményeitől. Továbbá azt is megállapítottuk, hogy a vizsgált tenzidkompozíciók $20 \mathrm{~mm}$ feletti, azaz megfelelő olajkimosó hatással rendelkezett.

\subsection{Emulgeáló hatás vizsgálata atmoszférikus nyomáson}

A kőolaj-rétegvizes tenzidoldattal elöállított emulziók atmoszférikus nyomáson történő emulgeáló kapacitását vizsgáltuk. A méréseinket $20^{\circ} \mathrm{C}$-on és $80^{\circ} \mathrm{C}$-on is elvégeztük, majd meghatározott időközönként feljegyeztük az egyes fázisok mennyiségét. A $20^{\circ} \mathrm{C}$-on végzett vizsgálataink eredményét a 2 . táblázatban, a $80^{\circ} \mathrm{C}$-on végzett méréseink eredményét pedig a 3. táblázatban adtuk meg.

2. táblázat. Emulgeáló hatás vizsgálata atmoszférikus nyomáson, $20^{\circ} \mathrm{C}$-on

\begin{tabular}{|c|c|c|c|c|c|c|}
\hline \multirow{4}{*}{ 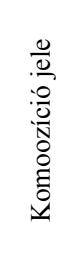 } & \multicolumn{6}{|c|}{$20^{\circ} \mathrm{C}$} \\
\hline & \multicolumn{3}{|c|}{$1 / 2$ óra } & \multicolumn{3}{|c|}{1 óra } \\
\hline & \multicolumn{6}{|c|}{ Fázis (V/V\%) } \\
\hline & $\begin{array}{l}=0 \\
\frac{\mathscr{D}}{0} \\
\text { I }\end{array}$ & $\begin{array}{l}=0 \\
0 \\
0 \\
0 \\
: 0 \\
0 \\
1\end{array}$ & $\stackrel{0}{0}$ & $\begin{array}{l}=0 \\
\frac{0}{0} \\
0 \\
1\end{array}$ & $\begin{array}{l}=0 \\
0 \\
000 \\
\text { N } \\
: 0 \\
01\end{array}$ & $\stackrel{\circ}{\gtrless}$ \\
\hline KO-1 & 55 & 0 & 45 & 47,5 & 7,5 & 45 \\
\hline $\mathrm{KO}-2$ & 52,5 & 0 & 47,5 & 55 & 0 & 45 \\
\hline $\mathrm{KO}-3$ & 52,5 & 2,5 & 45 & 52,5 & 2,5 & 45 \\
\hline $\mathrm{KO}-4$ & 60 & 0 & 40 & 60 & 0 & 40 \\
\hline $\mathrm{KO}-5$ & 75 & 0 & 25 & 70 & 0 & 30 \\
\hline
\end{tabular}

3. táblázat. Emulgeáló hatás vizsgálata atmoszférikus nyomáson, $80^{\circ} \mathrm{C}$-on

\begin{tabular}{|c|c|c|c|c|c|c|}
\hline \multirow{4}{*}{$\begin{array}{l}\frac{0}{0} \\
\frac{0}{0} \\
\frac{0}{0} \\
0 \\
O \\
0 \\
0 \\
0\end{array}$} & \multicolumn{6}{|c|}{$80^{\circ} \mathrm{C}$} \\
\hline & \multicolumn{3}{|c|}{1 óra } & \multicolumn{3}{|c|}{48 óra } \\
\hline & \multicolumn{6}{|c|}{ Fázis (V/V\%) } \\
\hline & $\begin{array}{l}=0 \\
0 \\
0 \\
0 \\
1\end{array}$ & $\begin{array}{l}=0 \\
0 \\
0 \\
0 \\
: 0 \\
1 \\
1\end{array}$ & $\stackrel{\circ}{\stackrel{0}{Z}}$ & $\begin{array}{l}: 0 \\
\frac{0}{0} \\
\text { I. }\end{array}$ & $\begin{array}{l}=0 \\
\text { ồ } \\
\text { N } \\
: 0 \\
1\end{array}$ & 道 \\
\hline KO-1 & 45 & 10 & 45 & 47,5 & 7,5 & 45 \\
\hline $\mathrm{KO}-2$ & 0 & 72,5 & 27,5 & 47,5 & 7,5 & 45 \\
\hline $\mathrm{KO}-3$ & 47,5 & 5 & 47,5 & 50 & 5 & 45 \\
\hline $\mathrm{KO}-4$ & 5 & 95 & 0 & 82,5 & 10 & 7,5 \\
\hline $\mathrm{KO}-5$ & 5 & 90 & 5 & 50 & 10 & 40 \\
\hline
\end{tabular}

Az eredmények alapján megállapítottuk, hogy míg a rétegkörülményektől különböző $20^{\circ} \mathrm{C}$-on csak jelentéktelen volt az emulzióképződés, addig $80^{\circ} \mathrm{C}$-on 1 óra után minden esetben keletkezett emulziós fázis. A $80^{\circ} \mathrm{C}$-on végzett méréseinket a 2 . ábra is szemlélteti. 


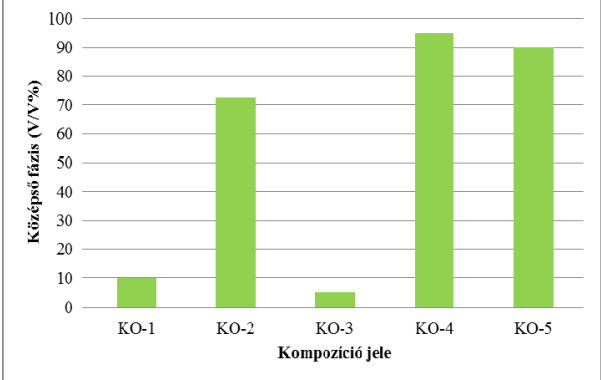

2. ábra. Emulgeáló hatás $80^{\circ} \mathrm{C}$-on, 1 óra után, középső fázis esetén

\subsection{Emulgeáló hatás vizsgálata rétegkörülményeket közelítő kondíciók mellett}

A kőolaj-rétegvizes tenzidoldat emulziókat nagy nyomású ( 10bar) szolubilizáló cellában vizsgáltuk. A nagynyomású cellában a kőolajtárolóból származó réteggázt használtuk fel. A kialakult fázisok arányát a 4. táblázat szemlélteti.

4. táblázat. Emulgeáló hatás vizsgálata, $80^{\circ} \mathrm{C}$, 10 bar

\begin{tabular}{|c|c|c|c|c|c|c|c|c|c|}
\hline \multirow{3}{*}{$\begin{array}{l}\frac{0}{0} \\
\frac{0}{0} \\
\frac{0}{0} \\
0 \\
0 \\
\frac{0}{0} \\
0\end{array}$} & \multicolumn{3}{|c|}{$\begin{array}{c}\text { Tároló gáz, } \\
98^{\circ} \mathrm{C}, \\
1 \text { óra }\end{array}$} & \multicolumn{3}{|c|}{$\begin{array}{c}\text { Tároló gáz, } \\
98^{\circ} \mathrm{C}, \\
4 \text { óra }\end{array}$} & \multicolumn{3}{|c|}{$\begin{array}{c}\text { Tároló gáz, } \\
98^{\circ} \mathrm{C}, \\
24 \text { óra }\end{array}$} \\
\hline & \multicolumn{9}{|c|}{ Fázis, v/v\%; nyomás, bar } \\
\hline & $\begin{array}{l}=0 \\
\frac{0}{0} \\
0 \\
1\end{array}$ & $\begin{array}{l}=0 \\
\mathscr{W} \\
0 \\
\text { No } \\
1\end{array}$ & $\frac{\%}{4}$ & $\begin{array}{l}=0 \\
\frac{00}{0} \\
10\end{array}$ & $\begin{array}{l}: 0 \\
\infty \\
0 \\
\text { N } \\
01\end{array}$ & \& & $\begin{array}{l}=0 \\
\frac{0}{0} \\
1\end{array}$ & $\begin{array}{l}: 0 \\
\text { Dे } \\
\text { N } \\
: 0 \\
1\end{array}$ & $\stackrel{\circ}{\gtrless}$ \\
\hline \multirow[t]{2}{*}{ KO-1 } & 60 & 0 & 45 & 60 & 0 & 45 & 58 & 0 & 45 \\
\hline & \multicolumn{3}{|c|}{9,0} & \multicolumn{3}{|c|}{10} & \multicolumn{3}{|c|}{11,5} \\
\hline \multirow[t]{2}{*}{$\mathrm{KO}-2$} & 50 & 0 & 50 & 50 & 0 & 50 & 50 & 0 & 50 \\
\hline & \multicolumn{3}{|c|}{10} & \multicolumn{3}{|c|}{11} & \multicolumn{3}{|c|}{10,5} \\
\hline \multirow[t]{2}{*}{$\mathrm{KO}-3$} & 58 & 0 & 50 & 60 & 0 & 50 & 60 & 0 & 50 \\
\hline & \multicolumn{3}{|c|}{9,8} & \multicolumn{3}{|c|}{10,3} & \multicolumn{3}{|c|}{10,1} \\
\hline \multirow[t]{2}{*}{$\mathrm{KO}-4$} & 0 & 85 & 15 & 60 & 0 & 45 & 55 & 0 & 45 \\
\hline & \multicolumn{3}{|c|}{8,8} & \multicolumn{3}{|c|}{9,0} & \multicolumn{3}{|c|}{8,8} \\
\hline \multirow[t]{2}{*}{$\mathrm{KO}-5$} & 45 & 5 & 50 & 45 & 5 & 50 & 45 & 5 & 50 \\
\hline & \multicolumn{3}{|c|}{11} & \multicolumn{3}{|c|}{10,8} & \multicolumn{3}{|c|}{10,5} \\
\hline
\end{tabular}

Megállapítottuk, hogy a nagy nyomáson végzett emulgeáló kapacitás vizsgálatakor középső fázis, azaz emulziós fázis csak jelentéktelen mértékben alakult ki. A kialakult kőolaj-víz elegy viszkozitása és sürüsége -a beoldódott gáz hatásáralecsökkent. Továbbá $\quad \sim 10 \%$ térfogatnövekedést tapasztaltunk, mely szintén a beoldódott gáz hatása volt.

\section{Következtetések}

Kémiai EOR célokra állítottunk elő tenzideket, illetve tenzidkompozíciókat, melyek jellemzésére különböző hatásvizsgálati módszereket dolgoztunk ki. A kidolgozott módszerek közül az olajkimosó hatás és az emulgeáló hatás vizsgálatát mutattuk be. A tenzidoldatok olajkimosó hatását vizsgálva azt találtuk, hogy a kőolajrétegből származó kőzetőrleménnyel végzett vizsgálatok eredménye eltér a modell vizsgálatokétól. Az előállított kőolaj-rétegvíz emulziókat vizsgáltuk atmoszférikus nyomáson és rétegkörülményeket közelítő kondíciók mellett. Megállapítottuk, hogy nagy nyomáson középső, emulziós fázis nem vagy csak alig keletkezik. Összességében megállapítottuk, hogy a felhasználandó tenzidek hatásvizsgálati módszereit célszerű az adott terület körülményeihez illeszteni.

\section{Szakirodalmi hivatkozások}

[1] James J. Sheng: Modern Chemical Enhanced Oil Recovery: Theory and Practice, Gulf Professional Publishing, 2010

[2] R. Nagy, L. Bartha, Á. Vágó: Investigation of Nonionic Surfactants for Enhanced Oil Recovery, Interfaces Sopron, 2011

[3] R. Nagy, R. Sallai, L. Bartha, Á. Vágó: Harmadlagos köolajkitermelésre alkalmas tenzidek kiválasztási módszerei, EMMITMüszaki Szemle 63., 2014

\section{Köszönetnyílvánítás}

A szerzők köszönetet mondanak a cikk elkészítéséért: MOL Nyrt., Csoportszintü Kutatás \& Üzletfejlesztés támogatásáért. 